

\title{
Aspects of the Coordination Chemistry of 1,1'-Di(benzothiazol-2-ylthio)ferrocene
}

Ulrich Siemeling, Alexander Girod, Dag Rother, Clemens Bruhn

\section{To cite this version:}

Ulrich Siemeling, Alexander Girod, Dag Rother, Clemens Bruhn. Aspects of the Coordination Chemistry of 1,1'-Di(benzothiazol-2-ylthio)ferrocene. Journal of Inorganic and General Chemistry / Zeitschrift für anorganische und allgemeine Chemie, 2009, 635 (9-10), pp.1402. 10.1002/zaac.200900084 . hal-00479611

\section{HAL Id: hal-00479611 \\ https://hal.science/hal-00479611}

Submitted on 1 May 2010

HAL is a multi-disciplinary open access archive for the deposit and dissemination of scientific research documents, whether they are published or not. The documents may come from teaching and research institutions in France or abroad, or from public or private research centers.
L'archive ouverte pluridisciplinaire HAL, est destinée au dépôt et à la diffusion de documents scientifiques de niveau recherche, publiés ou non, émanant des établissements d'enseignement et de recherche français ou étrangers, des laboratoires publics ou privés. 


\section{Aspects of the Coordination Chemistry of 1,1'- Di(benzothiazol-2-ylthio)ferrocene}

\begin{tabular}{|c|c|}
\hline Journal: & Zeitschrift für Anorganische und Allgemeine Chemie \\
\hline Manuscript ID: & zaac. 200900084 \\
\hline Wiley - Manuscript type: & Article \\
\hline $\begin{array}{r}\text { Date Submitted by the } \\
\text { Author: }\end{array}$ & 03-Feb-2009 \\
\hline Complete List of Authors: & $\begin{array}{l}\text { Siemeling, Ulrich; Universität Kassel, Institut für Chemie } \\
\text { Girod, Alexander; Universität Kassel, Institut für Chemie } \\
\text { Rother, Dag; Universität Kassel, Institut für Chemie } \\
\text { Bruhn, Clemens; Universität Kassel, Institut für Chemie }\end{array}$ \\
\hline Keywords: & Coordination polymers, Copper \\
\hline
\end{tabular}

\section{S) scholaroNE" \\ Manuscript Central}




\title{
Aspects of the Coordination Chemistry of 1,1'-Di(benzothiazol-2-ylthio)ferrocene
}

Ulrich Siemeling*, Alexander Girod, Dag Rother, and Clemens Bruhn

Kassel, Institut für Chemie der Universität

Received

\begin{abstract}
Di(benzothiazol-2-ylthio)ferrocene (1) acts as a bridging bidentate N,Nligand and affords coordination polymers with a range of $\mathrm{Cu}^{\mathrm{I}}, \mathrm{Ag}^{\mathrm{I}}, \mathrm{Cu}^{\mathrm{II}}, \mathrm{Zn}^{\mathrm{II}}$ and $\mathrm{Hg}^{\mathrm{II}}$ salts. The crystal structures of $\left[\mathrm{Ag}\left(\mathrm{CF}_{3} \mathrm{SO}_{3}\right)(\mu-\mathbf{1})\right]_{n},\left[\mathrm{CuCl}_{2}(\mu-\mathbf{1})\right]_{n},\left[\mathrm{ZnCl}_{2}(\mu-\mathbf{1})\right]_{n}$ and $\left[\mathrm{HgBr}_{2}(\mu-\right.$ 1) $]_{n}$ have been determined. The silver atom exhibits a weak contact to a cyclopentadienyl $\pi$-system in addition to its trigonal-planar coordination. The copper atom is in a squareplanar coordination environment, while the coordination of zinc and mercury is best described as distorted tetrahedral in the corresponding complexes.
\end{abstract}

Keywords: Coordination polymers; Copper; Mercury; Silver; Zinc

* Prof. Dr. U. Siemeling

Universität Kassel

Institut für Chemie

D-34109 Kassel

e-mail: siemeling@uni-kassel.de 


\section{Introduction}

We recently reported the synthesis and crystal structure of 1,1'-di(benzothiazol-2ylthio)ferrocene (1) [1]. This compound is a symmetrically disubstituted thioether derivative of ferrocene with pendant heterocyclic groups. It contains six potentially ligating heteroatoms, viz. two 'hard' nitrogen and four 'soft' sulfur atoms, two of which are directly connected to the ferrocene nucleus. Chelate complexes of 1,1'-dithioetherfunctionalised ferrocene derivatives which contain additional sulfur or nitrogen donor atoms in the periphery have been described for a wide range of 'soft' mono- and divalent metal centres, viz. $\mathrm{Rh}^{\mathrm{I}}, \mathrm{Cu}^{\mathrm{I}}, \mathrm{Ag}^{\mathrm{I}}, \mathrm{Au}^{\mathrm{I}}, \mathrm{Pd}^{\mathrm{II}}, \mathrm{Pt}^{\mathrm{II}}, \mathrm{Cu}^{\mathrm{II}}$ and $\mathrm{Hg}^{\mathrm{II}}$ [2]. Benzothiazole coordinates almost exclusively through its nitrogen atom. Reports concerning Scoordination are scarce [3], and no structurally characterised example is known. We have been interested in studying the binding profile of $\mathbf{1}$ towards a range of transition metal ions in order to probe the suitability of $\mathbf{1}$ as a molecular electrochemical sensor with potential selectivity for 'soft' metal ions. If in our case coordination occurs through the two thioether-type sulfur atoms, which are prone to bind preferentially to 'soft' metal centres, the effect on the redox potential of the ferrocene moiety is expected to be much larger than in the case of exclusive coordination through the nitrogen atoms of the pendant substituents. We note that one of the most efficient molecular sensors with pronounced $\mathrm{Hg}^{\mathrm{II}}$ selectivity contains two thioether units for metal coordination [4].

\section{Results and Discussion}

Ligand 1 was allowed to react in dichloromethane solution in a 1:1 ratio with $\mathrm{CuCl}_{2}$, $\mathrm{ZnCl}_{2}, \mathrm{HgCl}_{2}, \mathrm{HgBr}_{2}$ and also with $\left[\mathrm{Cu}\left(\mathrm{CH}_{3} \mathrm{CN}\right)_{4}\right]\left[\mathrm{PF}_{6}\right], \mathrm{Ag}\left(\mathrm{CF}_{3} \mathrm{SO}_{3}\right)$ and $\mathrm{AuCl}$. The 
reactions cleanly afforded coordination compounds in all cases but two. Coordination was affected by redox processes in the case of $\mathrm{AuCl}$, where formation of a gold mirror was observed, and $\mathrm{HgCl}_{2}$, where an intractable mixture was obtained whose dark colour indicated generation of elemental mercury. The metal complexes obtained turned out to be essentially insoluble in dichloromethane and other common organic solvents, suggesting that coordination polymers, instead of mononuclear chelates, had formed. Unfortunately, this behaviour prevents the use of $\mathbf{1}$ as a molecular electrochemical sensor in solution.

Structural characterisation by single crystal X-ray diffraction analysis was possible for $\left[\mathrm{CuCl}_{2}\right.$ (1)] (Fig. 1), [ $\mathrm{ZnCl}_{2}$ (1)] (Fig. 2), $\left[\mathrm{HgBr}_{2}(\mathbf{1})\right]$ (Fig. 3), and $\left[\mathrm{Ag}\left(\mathrm{CF}_{3} \mathrm{SO}_{3}\right)(\mathbf{1})\right]$ (Fig. 4). Suitable crystals were obtained by a diffusion technique, which involved layering of a solution of $\mathbf{1}$ with pure solvent and subsequently with a solution of the corresponding metal salt. All four complexes are coordination polymers. $\mathbf{1}$ exclusively acts as a bridging bidentate N,N-ligand. S-coordination is not observed. Possibly, thioether S-coordination occurs in the case of $\mathrm{AuCl}$ and $\mathrm{HgCl}_{2}$, but triggers intramolecular redox processes between the ferrocene nucleus and the metal centre coordinated in very close proximity. Uncoordinated 1 exhibits eclipsed cyclopentadienyl rings [1], while a staggered conformation with diametrically opposed substituents is observed for all four crystallographically characterised complexes. Metal coordination has no pronounced effect on intraligand bond lengths and angles. 


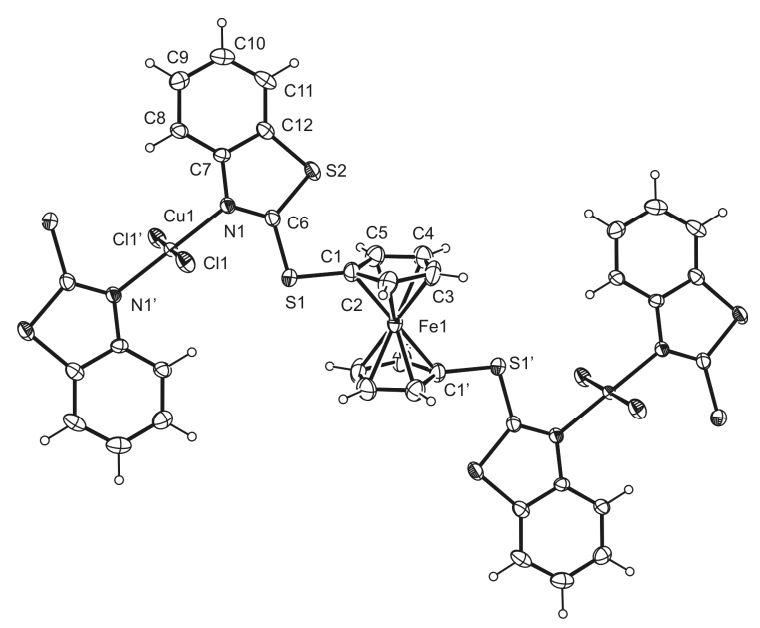

Fig.1 Short section of a polymeric chain of $\left[\mathrm{CuCl}_{2}(\mu-\mathbf{1})\right]_{n}$ in the crystal. Thermal displacement ellipsoids are drawn at the $30 \%$ probability level. Selected bond lengths $/ \AA$ and angles $/^{\circ}: \mathrm{Cu}(1)-\mathrm{Cl}(1) 2.2423(16), \mathrm{Cu}(1)-\mathrm{N}(1) 2.012(4), \mathrm{N}(1)-\mathrm{C}(6)$ 1.318(6), $\mathrm{N}(1)-\mathrm{C}(7)$ 1.408(5), S(1)-C(1) 1.767(5), S(1)-C(6) 1.744(5), S(2)-C(6) 1.750(5), $\mathrm{S}(2)-\mathrm{C}(12) 1.742(5) ; \mathrm{Cl}(1)-\mathrm{Cu}(1)-\mathrm{N}(1) 91.12(12)$.

The $\mathrm{Cu}$ atom of $\left[\mathrm{CuCl}_{2}(\mu-\mathbf{1})\right]_{n}$ is in a square-planar coordination environment. The ligands are in a trans arrangement. Bond lengths and angles are very similar to those reported for the closely related trans-dichlorobis(3,5-dimethylthiazole)copper(II) [5] and trans-dichlorodi(2-aminobenzothiazole)copper(II) [6], while the dichlorocopper(II) complex of (bzt-2) $)_{2}-O-\mathrm{C}_{6} \mathrm{H}_{4}$ (bzt-2 = benzothiazol-2-yl) is a cis-chelate which exhibits a notably distorted square-planar coordination [7]. We note that $\mathrm{Cu}^{\mathrm{II}}$ complexes which contain imidazole or related heterocyclic $\mathrm{N}$-ligands together with additional thioether ligands are currently attracting increased attention due to their relevance to the catalytic centre of peptidylglycine $\alpha$-hydroxylating monooxygenase (PHMcc) and related oxygenases with an essentially mononuclear catalytic core [8]. 


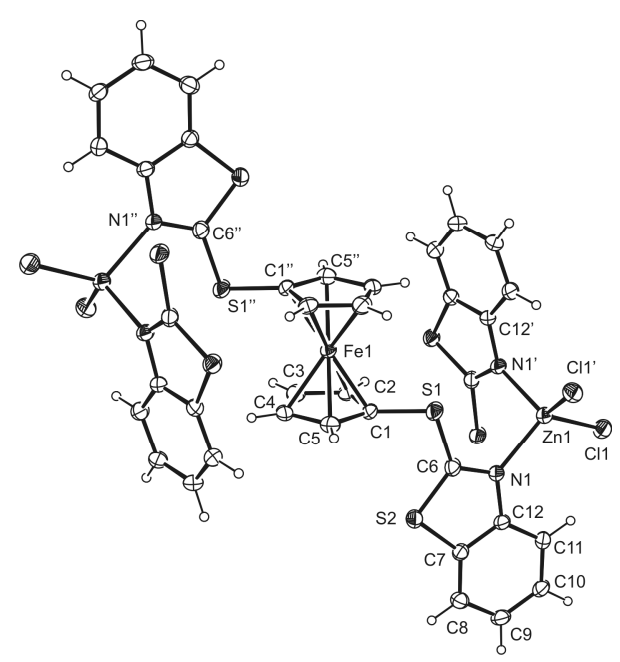

Fig. 2 Short section of a polymeric chain of $\left[\mathrm{ZnCl}_{2}(\mu-\mathbf{1})\right]_{n}$ in the crystal. Thermal displacement ellipsoids are drawn at the $30 \%$ probability level. Selected bond lengths/Å and angles/ ${ }^{\circ}: \mathrm{Zn}(1)-\mathrm{Cl}(1)$ 2.2343(13), Zn(1)-N(1) 2.106(3), N(1)-C(6) 1.318(6), $\mathrm{N}(1)-\mathrm{C}(12)$ 1.414(5), S(1)-C(1) 1.771(4), S(1)-C(6) 1.755(4); N(1)-Zn(1)-Cl(1) 116.62(10), N(1)-Zn(1)-Cl(1') 103.72(11).

The $\mathrm{Zn}$ atom of $\left[\mathrm{ZnCl}_{2}(\mu-\mathbf{1})\right]_{n}$ is in a distorted tetrahedral coordination environment. The $\mathrm{N}-\mathrm{Zn}-\mathrm{N}$ and $\mathrm{Cl}-\mathrm{Zn}-\mathrm{Cl}$ angles are $101.8(2)^{\circ}$ and $114.19(7)^{\circ}$, respectively. The corresponding angles are ca. $103.3^{\circ}$ and $116.8^{\circ}$ for the closely related $\left[\mathrm{ZnCl}_{2}\left(\mathrm{bzt}-7-\mathrm{NH}_{2}\right)\right]\left(\right.$ bzt-7 = benzothiazol-7-yl) [9] and ca. $116.3^{\circ}$ and $112.5^{\circ}$ for the bulkier thio-functionalised $\left[\mathrm{ZnCl}_{2}\left\{\mathrm{bzt}-2-\mathrm{N}=\mathrm{C}(\mathrm{SMe})_{2}\right\}\right][10]$. 


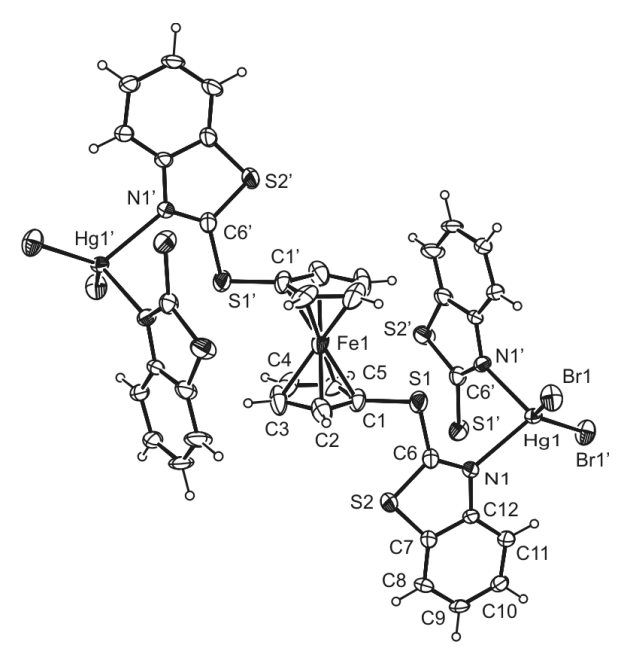

Fig. 3 Short section of a polymeric chain of $\left[\operatorname{HgBr}_{2}(\mu-1)\right]_{n}$ in the crystal. Thermal displacement ellipsoids are drawn at the $30 \%$ probability level. Selected bond lengths/ $\AA$ and angles/ ${ }^{\circ}: \operatorname{Hg}(1)-\mathrm{N}(1) 2.409(5), \mathrm{Hg}(1)-\mathrm{Br}(1)$ 2.4973(8), N(1)-C(6) 1.301(8), $\mathrm{N}(1)-\mathrm{C}(12)$ 1.427(7), S(1)-C(1) 1.769(6), S(1)-C(6) 1.762(7); N(1)-Hg(1)-Br(1) 98.84(13), N(1)-Hg(1)-Br(1') 116.09(12).

The $\mathrm{Hg}$ atom of $\left[\mathrm{HgBr}_{2}(\mu-\mathbf{1})\right]_{n}$ is in a very distorted tetrahedral coordination environment. The $\mathrm{N}-\mathrm{Hg}-\mathrm{N}$ and $\mathrm{Br}-\mathrm{Hg}-\mathrm{Br}$ angles are $90.1(2)^{\circ}$ and $130.32(4)^{\circ}$, respectively, which is similar to the corresponding values of ca. $89.9^{\circ}$ and $127.4^{\circ}$ reported for the closely related $\left[\mathrm{HgI}_{2}(\mathrm{bzt}-2-\mathrm{CH}=\mathrm{CHPh})\right][11]$. 


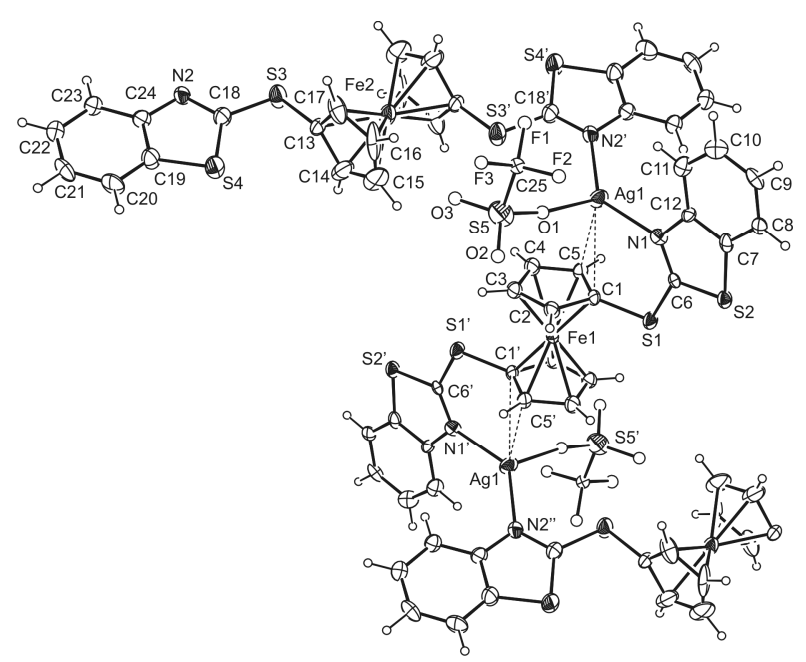

Fig. 4 Short section of a polymeric chain of $\left[\mathrm{Ag}\left(\mathrm{CF}_{3} \mathrm{SO}_{3}\right)(\mu-\mathbf{1})\right]_{n}$ in the crystal. Thermal displacement ellipsoids are drawn at the $30 \%$ probability level. $\mathrm{O}$ and $\mathrm{F}$ atoms are shown as circles of arbitrary size for clarity. Selected bond lengths/ $\AA$ : $\operatorname{Ag}(1)-\mathrm{N}(1) 2.215(7)$,

$$
\begin{gathered}
\operatorname{Ag}(1)-\mathrm{N}\left(2^{\prime}\right) \text { 2.177(8), } \operatorname{Ag}(1)-\mathrm{O}(1) 2.354(8), \mathrm{N}(1)-\mathrm{C}(6) 1.325(9), \mathrm{N}(1)-\mathrm{C}(12) 1.427(10), \\
\mathrm{S}(1)-\mathrm{C}(1) 1.768(8), \mathrm{S}(1)-\mathrm{C}(6) 1.757(8) .
\end{gathered}
$$

The Ag atom of $\left[\mathrm{Ag}\left(\mathrm{CF}_{3} \mathrm{SO}_{3}\right)(\mu-\mathbf{1})\right]_{n}$ is surrounded by two benzothiazole nitrogen atoms and one triflate oxygen atom in a distorted trigonal-planar arrangement. The $\mathrm{N}-\mathrm{Ag}-\mathrm{N}$ angle has a value of $135.5(3)^{\circ}$, while the two $\mathrm{N}-\mathrm{Ag}-\mathrm{O}$ angles are $117.7(4)^{\circ}$ and $96.3(4)^{\circ}$. The sum of angles is ca. $349.5^{\circ}$, which deviates considerably from the ideal value of $360^{\circ}$ and is indicative of a weak additional interaction. Indeed, the Ag atom forms a contact with one of the cyclopentadienyl ring. It is positioned almost perpendicularly with respect to one of the edges of this ring. The corresponding Ag-C distances of ca. 2.88 and $2.94 \AA$ (indicated by dotted lines in Fig. 4) are well below the sum of the estimated van der Waals radii of ca. $3.4 \AA$. A similar interaction between a ferrocene-type $\pi$-system and an $\mathrm{Ag}^{\mathrm{I}}$ centre has been reported by Laguna and coworkers for $\left[\mathrm{Ag}\left\{\mathrm{fc}\left(\mathrm{S}_{2} \mathrm{CNEt}_{2}\right)_{2}\right\}\right]_{n}\left[\mathrm{ClO}_{4}\right]_{n}(\mathrm{fc}$ 
= 1,1'-ferrocenediyl), where the corresponding Ag-C distances are close to $3.0 \AA$ [12]. Coordinative interactions between $\mathrm{Ag}^{\mathrm{I}}$ and aromatic $\pi$-systems have been firmly established [13] ever since the seminal crystal structure determination of the benzene complex $\left[\mathrm{Ag}\left(\mu-\eta^{2}: \eta^{2}-\mathrm{C}_{6} \mathrm{H}_{6}\right)\right]_{n}\left[\mathrm{ClO}_{4}\right]_{n}[14]$.

Crystals of the product obtained from the reaction of $\mathbf{1}$ with $\mathrm{Cu}\left[\mathrm{PF}_{6}\right]$ proved to be unsuitable for a single-crystal X-ray structure analysis. The insolubility of this compound clearly indicates the polymeric nature of this complex, which therefore can be formulated as $[\mathrm{Cu}(\mu-\mathbf{1})]_{n}\left[\mathrm{PF}_{6}\right]_{n}$. However, details of the $\mathrm{Cu}^{\mathrm{I}}$ coordination environment remain unclear.

\section{Experimental Part}

1,1'-Di(benzothiazol-2-ylthio)ferrocene (1) was prepared as described previously [1]. All other materials were procured from standard commercial sources and used as received. Elemental analyses were performed by the microanalytical laboratories of the University of Kassel and the University of Halle.

\section{General procedure for the preparation of the metal complexes}

In the case of $\left[\mathrm{Cu}\left(\mathrm{CH}_{3} \mathrm{CN}\right)_{4}\right]\left[\mathrm{PF}_{6}\right]$ and $\mathrm{Ag}\left(\mathrm{CF}_{3} \mathrm{SO}_{3}\right)$ as starting material a solution of the metal salt $(0.10 \mathrm{mmol})$ in dichloromethane $(5 \mathrm{~mL})$ was added rapidly to a stirred solution of $1(52 \mathrm{mg}, 0.10 \mathrm{mmol})$ in dichloromethane (5 mL). In the case $\mathrm{CuCl}_{2}, \mathrm{ZnCl}_{2}$ and $\mathrm{HgBr}_{2}$ as starting material a solution of the metal salt in acetone $(5 \mathrm{~mL})$ was used. The reaction mixture was allowed to stand at room temperature in the dark for $14 \mathrm{~h}$. The precipitate was isolated by filtration, washed with dichloromethane $(2 \times 0.5 \mathrm{~mL})$ and dried in vacuo. 
$[\mathbf{C u}(\mu-1)]_{n}\left[\mathbf{P F}_{6}\right]_{n}$ : yellow, microcrystalline solid (64 mg, 88\%). Elemental analysis:

$\mathrm{C}_{24} \mathrm{H}_{16} \mathrm{~N}_{2} \mathrm{~S}_{4} \mathrm{CuF}_{6} \mathrm{FeP}$ (725.02): C 38.81 (calcd. 39.76), H 2.55 (2.24), N 3.83 (3.86), S 17.11 (17.69).

$\left[\mathbf{A g}\left(\mathbf{C F}_{3} \mathbf{S O}_{3}\right)(\mu-1)\right]_{n}$ : yellow, microcrystalline solid (66 mg, 85\%). Elemental analysis: $\mathrm{C}_{25} \mathrm{H}_{16} \mathrm{~N}_{2} \mathrm{~S}_{5} \mathrm{AgF}_{3} \mathrm{FeO}_{3}$ (773.42): C 38.70 (calcd. 38.82), H 2.54 (2.09), N 3.77 (3.62), $\mathrm{S}$ 17.01 (16.58).

$\left[\mathrm{CuCl}_{2}(\mu-1)\right]_{n}$ : brown, microcrystalline solid (54 mg, 83\%). Elemental analysis: $\mathrm{C}_{24} \mathrm{H}_{16} \mathrm{~N}_{2} \mathrm{~S}_{4} \mathrm{Cl}_{2} \mathrm{CuFe}$ (650.97): C 43.56 (calcd. 44.28), H 2.54 (2.48), N 4.24 (4.30), S 18.85 (19.70).

$\left[\mathbf{Z n C l}_{2}(\mu-1)\right]_{n}$ : yellow, microcrystalline solid $(56 \mathrm{mg}, 86 \%)$. Elemental analysis: $\mathrm{C}_{24} \mathrm{H}_{16} \mathrm{~N}_{2} \mathrm{~S}_{4} \mathrm{Cl}_{2} \mathrm{FeZn}$ (652.75): C 43.65 (calcd. 44.16), H 2.94 (2.47), N 4.30 (4.29), S 19.35 (19.65).

$\left[\operatorname{HgBr}_{2}(\mu-1)\right]_{n}$ : dark yellow, microcrystalline solid (74 mg, 84\%). Elemental analysis: $\mathrm{C}_{24} \mathrm{H}_{16} \mathrm{~N}_{2} \mathrm{~S}_{4} \mathrm{Br}_{2} \mathrm{FeHg}$ (876.89): C 33.44 (calcd. 32.87), H 2.35 (1.84), N 3.52 (3.19), S $14.66(14.63)$

\section{X-ray crystallography}

Single crystals were obtained by a diffusion technique which involved layering of a dichloromethane solution of $\mathbf{1}$ with pure dichloromethane and subsequently with a solution 
of the corresponding metal salt in acetone or dichloromethane. For each data collection a single crystal was mounted on a glass fibre and all geometric and intensity data were taken from this sample. Data collection using MoKa radiation $(\lambda=0.71073 \AA)$ was made on a Stoe IPDS2 diffractometer equipped with a 2-circle goniometer and an area detector. Absorption correction was done by integration using X-red [15]. The data sets were corrected for Lorentz and polarisation effects. The structures were solved by direct methods (SHELXS97) and refined using alternating cycles of least squares refinements against $F^{2}$ (SHELXL97) [16]. All non H atoms were found in difference Fourier maps and were refined with anisotropic displacement parameters, except $\mathrm{C}(25)$ in the silver complex $\left[\mathrm{Ag}\left(\mathrm{CF}_{3} \mathrm{SO}_{3}\right)(\mu-1)\right]$ which was refined isotropically. $\mathrm{H}$ atoms were placed in constrained positions according to the riding model with the 1.2 fold isotropic displacement parameters. Pertinent crystallographic data are collected in Table 1. Graphical representations were made using ORTEP-3 win [17].

Supplementary Material. Crystallographic data (excluding structure factors) for the structures reported in this paper have been deposited with the Cambridge Crystallographic Data Centre as supplemental publication CCDC-713654 ([CuCl $\left.2(\mathbf{1})] \cdot \mathrm{CH}_{2} \mathrm{Cl}_{2}\right), \mathrm{CCDC}$ $713655\left(\left[\mathrm{ZnCl}_{2}(\mathbf{1})\right]\right), \mathrm{CCDC}-713656\left(\left[\mathrm{HgBr}_{2}(\mathbf{1})\right]\right)$ and CCDC-713657-([Ag( $\left.\left.\left(\mathrm{CF}_{3} \mathrm{SO}_{3}\right)(\mathbf{1})\right]\right)$. Copies of the data can be obtained free of charge on application to The Director, CCDC, 12 Union Road, Cambridge CB2 1 EZ, UK (Fax: int.code+(1223)336-033; e-mail for enquiry: fileserv@ccdc.cam.ac.uk). 
Table 1 Crystal data and structure refinement for the coordination polymers $\left[\mathrm{CuCl}_{2}(\mathbf{1})\right],\left[\mathrm{ZnCl}_{2}(\mathbf{1})\right]$, $\left[\mathrm{HgBr}_{2}(\mathbf{1})\right]$ and $\left[\mathrm{Ag}\left(\mathrm{CF}_{3} \mathrm{SO}_{3}\right)(\mathbf{1})\right]$

\begin{tabular}{|c|c|c|c|c|}
\hline Compound & {$\left[\mathrm{CuCl}_{2}(\mathbf{1})\right] \cdot \mathrm{CH}_{2} \mathrm{Cl}_{2}$} & {$\left[\mathrm{ZnCl}_{2}(\mathbf{1})\right]$} & {$\left[\mathrm{HgBr}_{2}(\mathbf{1})\right]$} & {$\left[\mathrm{Ag}\left(\mathrm{CF}_{3} \mathrm{SO}_{3}\right)(\mathbf{1})\right]$} \\
\hline Empirical formula & $\mathrm{C}_{25} \mathrm{H}_{18} \mathrm{Cl}_{4} \mathrm{CuFeN}_{2} \mathrm{~S}_{4}$ & $\mathrm{C}_{24} \mathrm{H}_{16} \mathrm{Cl}_{2} \mathrm{FeN}_{2} \mathrm{~S}_{4} \mathrm{Zn}$ & $\mathrm{C}_{24} \mathrm{H}_{16} \mathrm{Br}_{2} \mathrm{FeHgN}_{2} \mathrm{~S}_{4}$ & $\mathrm{C}_{25} \mathrm{H}_{16} \mathrm{AgF}_{3} \mathrm{FeN}_{2} \mathrm{O}_{3} \mathrm{~S}_{5}$ \\
\hline Formula weight & 735.89 & 652.75 & 876.89 & 773.42 \\
\hline Temperature / K & $153(2)$ & $153(2)$ & $173(2)$ & $213(2)$ \\
\hline Crystal system & monoclinic & monoclinic & monoclinic & triclinic \\
\hline Space group & $C 2 / c$ & $C 2 / c$ & $C 2 / c$ & $P-1$ \\
\hline Lattice parameters & $a=24.871(9)$ & $a=14.271(2)$ & $a=15.4795(15)$ & $a=8.9260(18)$ \\
\hline \multirow[t]{2}{*}{ length / $\AA$} & $b=9.205(5)$ & $b=12.9492(14)$ & $b=12.3068(12)$ & $b=10.208(2)$ \\
\hline & $c=16.612(4)$ & $c=14.910(2)$ & $c=15.3354(15)$ & $c=15.643(3)$ \\
\hline \multirow[t]{3}{*}{ angle $/^{\circ}$} & $\beta=130.469(17)$ & $\beta=116.271(11)$ & $\beta=118.252(7)$ & $\alpha=100.485(15)$ \\
\hline & & & & $\beta=98.867(15)$ \\
\hline & & & & $\gamma=95.070(16)$ \\
\hline Cell volume / $\AA^{3}$ & $2893(2)$ & $2470.9(6)$ & $2573.4(5)$ & $1374.9(5)$ \\
\hline$Z$ & 4 & 4 & 4 & 2 \\
\hline$d_{\text {calc. }} / \mathrm{gcm}^{-3}$ & 1.689 & 1.755 & 2.263 & 1.868 \\
\hline$\mu / \mathrm{mm}^{-1}$ & 1.915 & 2.130 & 9.970 & 1.673 \\
\hline$F(000)$ & 1476 & 1312 & 1656 & 768 \\
\hline$\theta$ range $I^{\circ}$ & 2.15 to 25.0 & 2.24 to 25.0 & 2.23 to 25.18 & 1.34 to 25.0 \\
\hline \multirow[t]{3}{*}{ Index ranges } & $-29 \rightarrow \mathrm{h} \rightarrow 29$ & $-16 \rightarrow \mathrm{h} \rightarrow 16$ & $-18 \rightarrow \mathrm{h} \rightarrow 18$ & $-10 \rightarrow \mathrm{h} \rightarrow 10$ \\
\hline & $-10 \rightarrow \mathrm{k} \rightarrow 10$ & $-11 \rightarrow \mathrm{k} \rightarrow 15$ & $-14 \rightarrow \mathrm{k} \rightarrow 14$ & $-12 \rightarrow \mathrm{k} \rightarrow 12$ \\
\hline & $-19 \rightarrow 1 \rightarrow 19$ & $-17 \rightarrow 1 \rightarrow 17$ & $-18 \rightarrow 1 \rightarrow 18$ & $-18 \rightarrow 1 \rightarrow 17$ \\
\hline Refls. collected & 9083 & 6474 & 8238 & 8998 \\
\hline Independent refls. & $2542\left[R_{\mathrm{int}}=0.0915\right]$ & $2177\left[R_{\mathrm{int}}=0.0874\right]$ & $2250\left[R_{\mathrm{int}}=0.0695\right]$ & $4568\left[R_{\text {int }}=0.0879\right]$ \\
\hline Refls. observed & 1348 & 1627 & 1934 & 1686 \\
\hline$T_{\min } / T_{\max }$ & 0.7899 and 0.9090 & 0.7866 and 0.8586 & 0.2135 and 0.2977 & 0.8340 and 0.9682 \\
\hline Data / restraints / parameters & $2542 / 0 / 171$ & $2177 / 0 / 156$ & $2250 / 0 / 156$ & $4568 / 3 / 359$ \\
\hline GOF on $F^{2}$ & 0.723 & 0.943 & 1.035 & 0.647 \\
\hline Final $R$ indices & $R 1=0.0391$ & $R 1=0.0434$ & $R 1=0.0328$ & $R 1=0.0501$ \\
\hline$[I>2 \sigma(I)]$ & $w R 2=0.0657$ & $w R 2=0.1074$ & $w R 2=0.0767$ & $w R 2=0.0820$ \\
\hline$R$ indices & $R 1=0.0391$ & $R 1=0.0594$ & $R 1=0.0393$ & $R 1=0.1395$ \\
\hline (all data) & $w R 2=0.0961$ & $w R 2=0.1134$ & $w R 2=0.0787$ & $w R 2=0.0951$ \\
\hline Largest diff. peak and hole / $\mathrm{e}^{-3}$ & 0.356 and -0.458 & 0.555 and -0.649 & 0.731 and -1.454 & 1.643 and -0.553 \\
\hline
\end{tabular}




\section{References}

[1] T. Weidner, N. Ballav, M. Zharnikov, A. Priebe, N. J. Long, J. Maurer, R. Winter, A. Rothenberger, D. Fenske, D. Rother, C. Bruhn, H. Fink, U. Siemeling, Chem. Eur. J. 2008, $14,4346$.

[2] Reviews: a) U. Siemeling in Ferrocenes: Ligands, Materials and Biomolecules, P. Štěpnička (ed.), Wiley, Chichester, 2008, chapter 4; b) U. Siemeling, T.-C. Auch, Chem. Soc. Rev. 2005, 34, 584.

[3] a) S. Karahan, P. Kose, E. Subasi, H. Alp, H. Temel, Transition Met. Chem. 2008, 33, 849; b) N. Karaböcek, S. Karaböcek, H. Mazlum, İ. Değirmencioğlu, K. Serbest, Turk. J. Chem. 2004, 28, 87; c) E. J. Duff, M. N. Hughes, K. J. Rutt, J. Chem. Soc. A 1968, 2354. [4] E. M. Nolan, S. J. Lippard, J. Am. Chem. Soc. 2007, 129, 5910.

[5] D. P. Gavel, D. J. Hodgson, Acta Crystallogr. B 1979, 35, 2704.

[6] W. Maniukiewicz, Acta Crystallogr. E 2004, 60, m340.

[7] a) J. C. T. Rendell, L. K. Thompson, Can. J. Chem. 1979, 57, 1; R. G. Ball, J. Trotter, Can. J. Chem. 1979, 57, 1368.

[8] a) Review: Y. Lee, D. Karlin in Concepts and Models in Bioinorganic Chemistry, H.-B. Kraatz, N. Metzler-Nolte (eds), Wiley-VCH, Weinheim, 2006, chapter 16; selected recent papers concerning PHM model systems: b) L. Zhou, K. M. Nicholas, Inorg. Chem. 2008, 47, 4356; c) Y. Lee, D.-H. Lee, A. A. Narducci-Sarjeant, L. N. Zakharov, A. L. Rheingold, K. D. Karlin, Inorg. Chem. 2006, 45, 10098.

[9] Z. Popovic, G. Pavlovic, Z. Soldin, V. Tralic-Kulenovic, L. Racané, Acta Crystallogr. C 2003, 59, m4. 
[10] F. Téllez, A. Flores-Parra, N. Barba-Behrens, S. Contreras, Polyhedron 2004, 23, 2481.

[11] L. P. Battaglia, A. Bonamartini Corradi, M. R.Cramarossa, I. M.Vezzosi, J. G.Giusti, Polyhedron 1993, 12, 2235.

[12] O. Crespo, M. C. Gimeno, P. G. Jones, A. Laguna, C. Sarroca, J. Chem. Soc., Chem. Commun. 1998, 1481.

[13] For a recent review, see: M. Munakata, L. P. Wu, G. L. Ning, Coord. Chem. Rev. 2000, 198, 171.

[14] R. E. Rundle, J. H. Goring, J. Am. Chem. Soc. 1950, 72, 5337.

[15] Stoe \& Cie, X-red ver. 1.06, Program for numerical absorption correction, Darmstadt, 2004.

[16] G. M. Sheldrick, SHELXS 97 and SHELXL 97, Programs for crystal structure solution and refinement, University of Göttingen, Germany, 1997.

[17] L. J. Farrugia, J. Appl. Crystallogr. 1999, 32, 837. 